\title{
Fecundity performance of nilem (Osteochilus vittatus) from Cianjur, Tasikmalaya and Kuningan Districts, West Java, Indonesia
}

\author{
RITA ROSTIKA", YULI ANDRIANI, JUNIANTO"v \\ Faculty of Fisheries and Marine Science, Universitas Padjadjaran. Jatinangor, Sumedang 45363, West Java, Indonesia. Tel.: +62-22-87701519, Fax.: \\ +62-22-87701518, vemail: ritarostika_unpad@yahoo.com, vv anto_lisc@yahoo.com
}

Manuscript received: 15 May 2017. Revision accepted: 15 June 2017.

\begin{abstract}
Rostika R, Andriani Y, Junianto. 2017. Fecundity performance of nilem (Osteochilus vittatus) from Cianjur, Tasikmalaya and Kuningan Districts, West Java, Indonesia. Asian J Agric 1: 17-21. The aim of this study was to know the reproduction aspects of nilem (Osteochilus vittatus Valenciennes, 1842; syn. Osteochilus hasseltii Valenciennes, 1842). The study was conducted from October 2015 to March 2016. This research included elements of body length, weight, gonad maturity level (GML) and fecundity. There were 27 samples collected from farming activities in Cianjur, Tasikmalaya and Kuningan West Java, Indonesia. The parameters observed were the correlation between weight and fecundity, correlation between body length and fecundity and GML. The method used was explorative approach and the data were analyzed by descriptive approach. The results showed that the correlation between weight and fecundity in Cianjur District was $\mathrm{y}=\mathrm{e}^{0,024 \mathrm{x}}$, while the body length and fecundity was $\mathrm{y}=\mathrm{e}^{0,413 \mathrm{x}}$. In Tasikmalaya District was $\mathrm{y}=\mathrm{e}^{0,0728 \mathrm{x}}$, while the body length and fecundity was $\mathrm{y}=\mathrm{e}^{0,4903 \mathrm{x}}$. In Kuningan District was $\mathrm{y}=\mathrm{e}^{0,2902 \mathrm{x}}$, while the correlation between the length of the fish and fecundity was $\mathrm{y}=\mathrm{e}^{0,6859 x}$. The dominant gonad maturity level of $O$. vittatus in Cianjur was GML IV (50\%), Tasikmalaya was GMLVI (100\%), and Kuningan was GML V (55,56\%) respectively. The relationship between length and body weight of Osteochillus vittatus from Cianjur, Tasikmalaya and Kuningan District were $\mathrm{W}=0,03 \mathrm{~L}^{2,95}, \mathrm{~W}=0.04 \mathrm{~L}^{2.89}$ and $\mathrm{W}=0.04 \mathrm{~L}^{2.79}$ respectively. The implication of this research was to understand the proper size of $O$. vittatus that can be harvested that have an optimum egg volume.
\end{abstract}

Keywords: Fecundity, GML, LW relationship, Osteochilus vittatus, West Java

\section{INTRODUCTION}

Nilem or Osteochilus vittatus (Valenciennes, 1842), syn. Osteochilus hasseltii (Valenciennes, 1842) is a freshwater fish that has been known as one of the prominent fish farming commodities in Java Island, particularly in the areas of Priangan, West Java. However, in recent years, the activities related to the industry have been gradually changed by the other similar emerging industries (Subagja et al. 2006) whereas the fish possesses propitious characteristics suitable for business, as the egg performance has shown good aspects of fecundity. $O$. vittatus has potential for both superior reproduction and fecundity. A pair of fish with weights between 100-150 g may produce 15,000-30,000 eggs (Yudhistira 2013). Their fecundity also may increase in logarithmic patterns as the fish grows both in length and weight. The eggs have been consumed widely for the taste and exported to several countries as an alternative for caviar.

Measurement of length-weight fish correlation shows standardized size of the fish at various locations related to the length and weight. This measurement is used to perform the character of the species. This correlation is important information to identify the growth rate (Isa et al. 2010). It is also one of the factors considered in determining fishery management strategies (Mansor et al. 2015).

Farming and industrial activities of $O$. vittatus in West Java are mainly centralized in the District of Ciamis and
Tasikmalaya (Department of Fisheries and Marines, West Java 2010). The objective of this research was to recognize the reproductional growth pattern of $O$. vittatus that includes length-weight correlation, gonad maturity level (GML), fecundity, as well as the management strategies for preparing maximum egg for the "egg crispy cookies".

Fecundity is related to the total length and body weight of fish. The environment, especially the availability of food in the habitat, is an important factor influencing the quality of eggs and the timing of reproduction. Lack of food can cause a delay in the maturation of the gonad resulting in low fecundity. Fish nutrition and diet can be determinant factors controlling population density, growth and fish condition. The feeding behavior of a species usually depends on the age, place/habitat, time and digestive tract of the fish itself (Syandri et al. 2015).

\section{MATERIALS AND METHODS}

This research was conducted from October 2015 to March 2016. Fish samples were taken from 3 different farming locations (Muchlisin et al. 2015) i.e., Cianjur, Kuningan, and Tasikmalaya in the West Java Province (Figure 1). Samples were observed and identified in the Laboratory of Aquaculture, Faculty of Fisheries and Marines, Universitas Padjadjaran, Sumedang, West Java, Indonesia. 

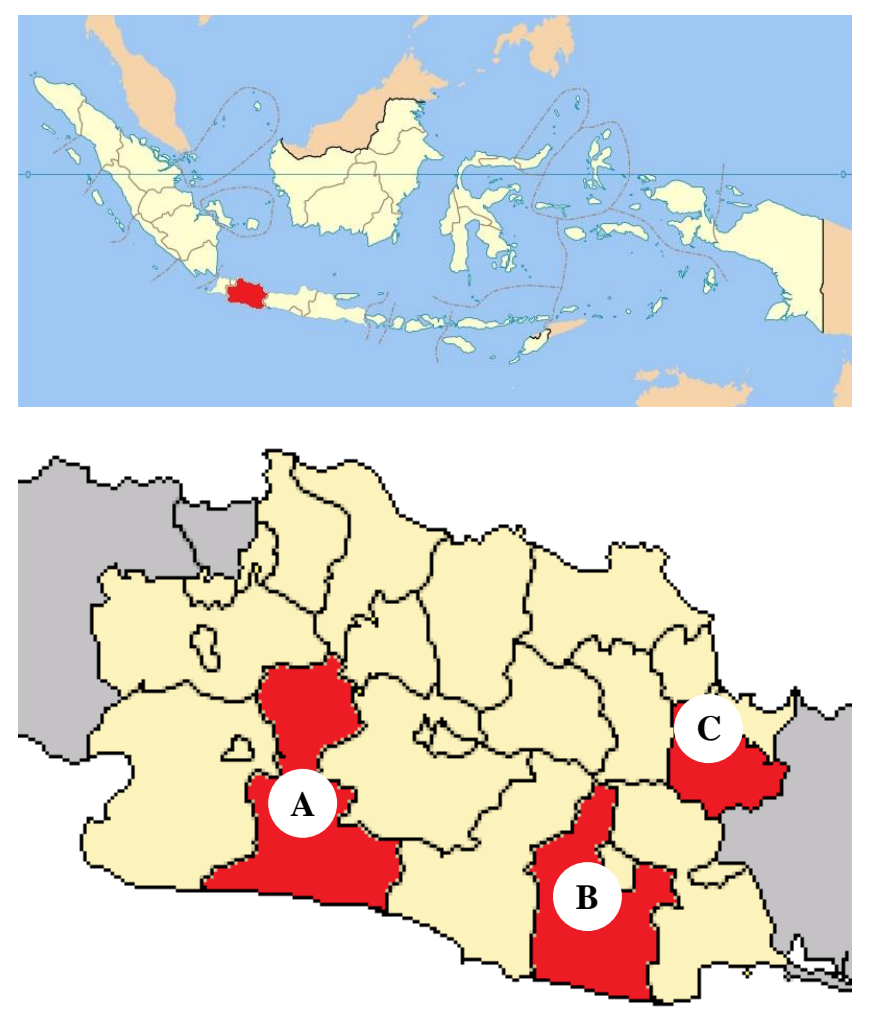

Figure 1. Research area in West Java, Indonesia (red color). A. Cianjur, B. Tasikmalaya, and C. Kuningan

The female breeder consists of 27 fish taken and froze for further observation in weight (in gram), length (in centimeter) and gonad maturity level (GML). Identification of Gonad Maturity Level refers to Kesteven (Bagenal and Braum 1968). Number of eggs was counted by gravimetric method. Fecundity was measured with the following formula (Effendie 1979):

$$
F=\frac{G \cdot x}{g}
$$

Note:

$\mathrm{F}$ = fecundity;

$\mathrm{x} \quad=$ number of sampling eggs;

$\mathrm{G} \quad=$ total gonad weight $(\mathrm{g})$;

$\mathrm{g} \quad=$ sample gonad weight $(\mathrm{g})$

The length-weight correlation was analyzed using the following formula (Effendie 1979; Brodziak 2012):
$\mathrm{W}=\mathrm{a} \mathrm{L}^{\mathrm{b}}$

The linearization could be done through logarithmic transformation using the following equation:

$\log W=\log a+b \log L$

Note

$\mathrm{W}=$ weight $(\mathrm{g})$

$\mathrm{L}=$ length $(\mathrm{mm})$

$\mathrm{a}=$ Intercept (curved intersection of length-weight correlation with the y-axis)

$\mathrm{b}=$ Length-weight coefficient assumption

\section{RESULTS AND DISCUSSION}

\section{Reproductions aspect}

The following are the results from the observation and treatment of the sampling in Cianjur, Kuningan, and Tasikmalaya that include total length (TL), body weight, gonad weight, gonad maturity level (GML), and fecundity (Table 1).

\section{Fecundity}

Fecundity is the number of eggs per unit of weight or length (Effendi 1979). The ovary weight may be resorted to make a presumption of the fecundity to get the expected results (Murtejo 2008). The observed fish weighed approximately $108-418 \mathrm{~g}$, and the fecundity is 26,200 123,880 eggs and the gonad weight range is $25-95 \mathrm{~g}$ (Table $1)$. The fecundity level in this research fluctuated possibly due to the age and size differences of the fish that results in the variation of the number of fecundity. It means that the bigger the fish, the higher the fecundity. Longer fish also tended to have higher fecundity (Figure 2-4). Fish with the highest fecundity (total length of $28.5 \mathrm{~cm}$ ) is in the GML VI (the spawning period).

It is also noted that the fish weight measurement is more reliable to presume the fecundity than the total body length. Absolute fecundity is often shown by the relation to the body weight, as it could approach the fish condition better than their body length (Effendie 1979). The relationship between fecundity and weight (Figure 5-7) appears as in general; heavy fish also have high fecundity, even the highest fecundity (weight $373 \mathrm{~g}$ ) in this research is achieved by fish in the spawning GML. Fluctuation occurs due to the age difference and the intensity of the spawning.

Table 1. Average reproductions aspects of $O$. vittatus in Cianjur, Tasikmalaya and Kuningan, West Java, Indonesia

\begin{tabular}{lllllll}
\hline Sample origin & TL $(\mathbf{c m})$ & SL $(\mathbf{c m})$ & Weight $(\mathbf{g})$ & Gonad $(\mathbf{g})$ & GML & Fecundity $($ eggs) \\
\hline Cianjur & 21.1 & 17.30 & 139.8 & 29.8 & GML IV-V & 30418 \\
Tasikmalaya & 27.4 & 22.16 & 356.0 & 72.3 & GML VI & 88954 \\
Kuningan & 10.6 & 7.84 & 20.9 & 8.62 & GML IV-VI & 109530 \\
\hline
\end{tabular}

Note: $\mathrm{TL}=$ total length, $\mathrm{SL}=$ Standard length, $\mathrm{GML}=$ gonad maturity level 

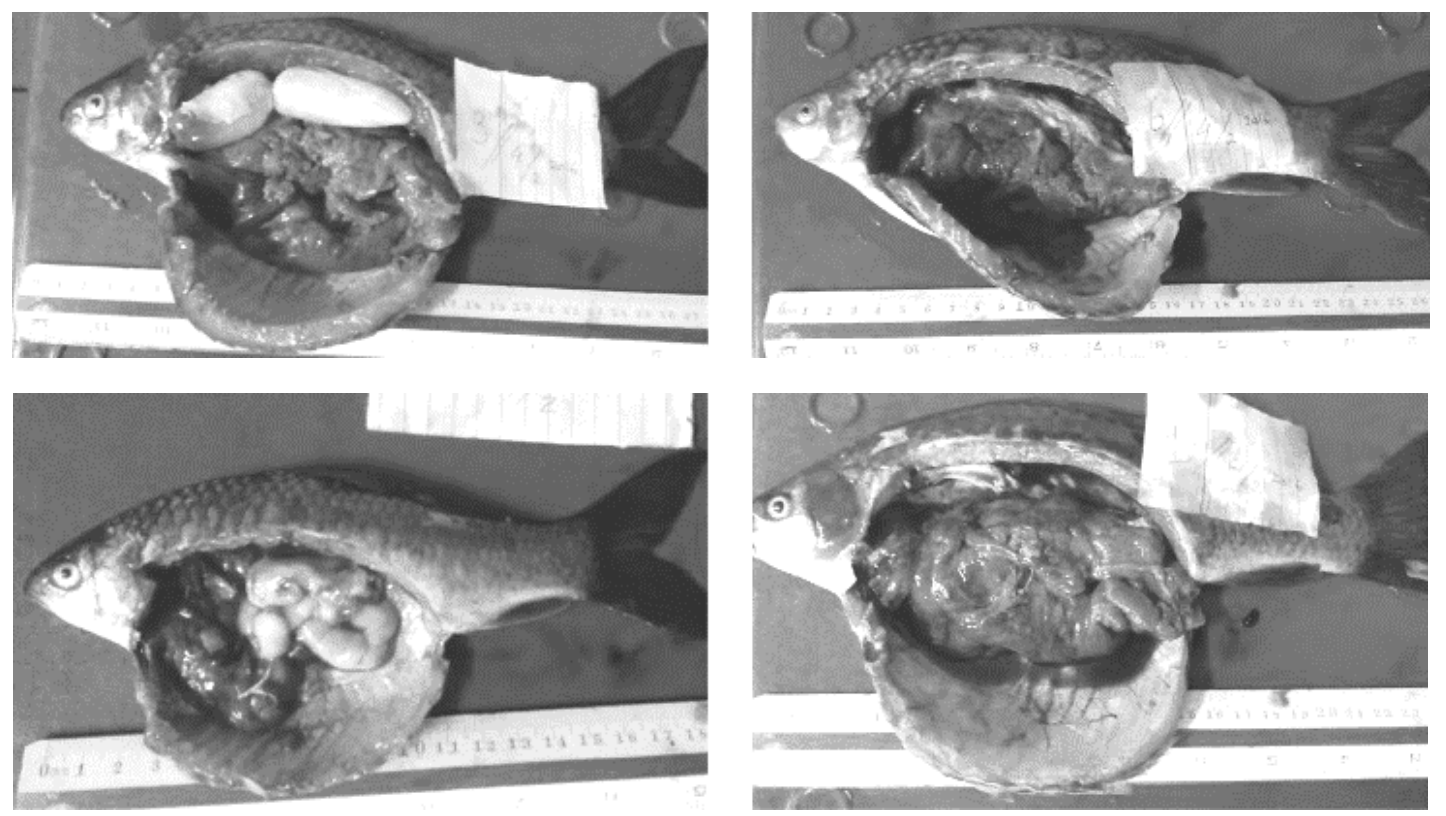

Figure 2. Egg profile of Ostechilus vittatus from Cianjur District, West Java, Indonesia
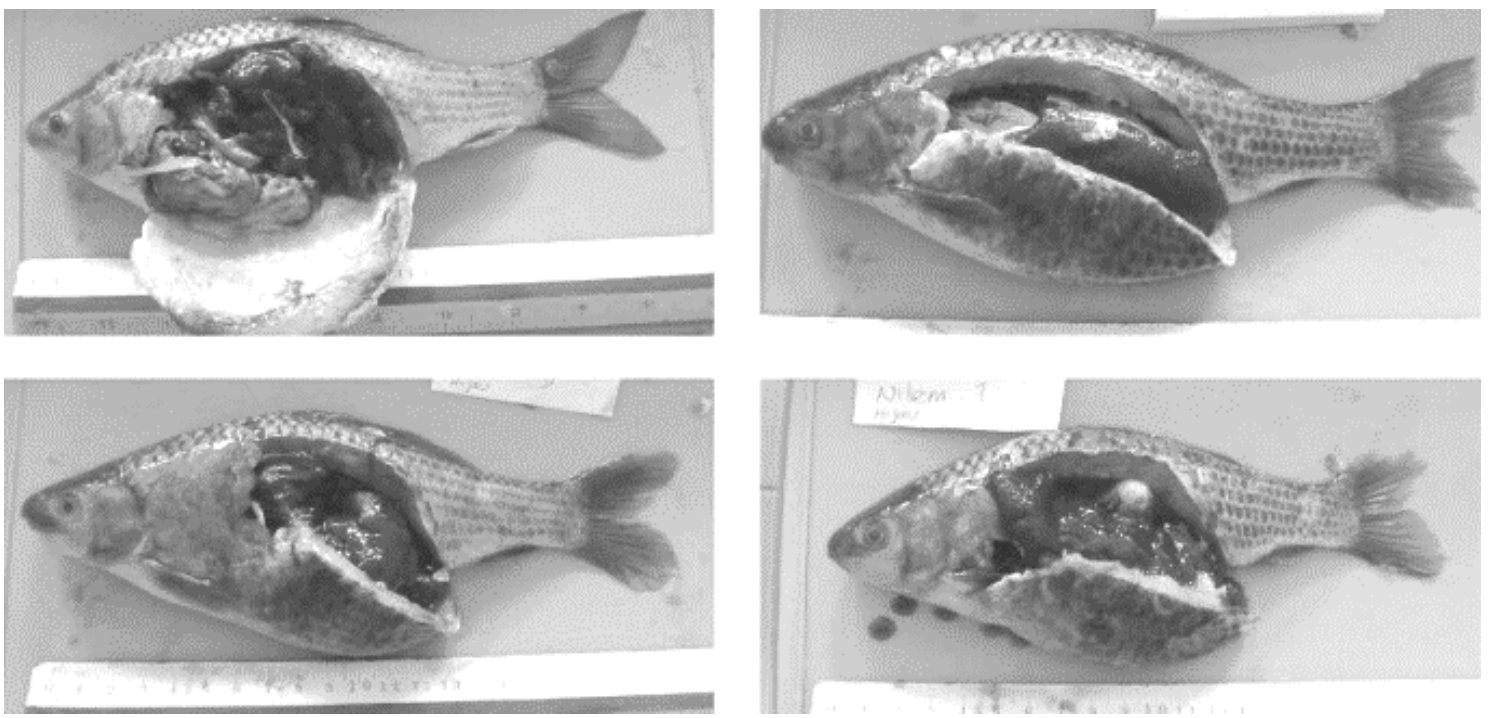

Figure 3. Egg Profile of Ostechilus vittatus from Tasikmalaya District, West Java, Indonesia
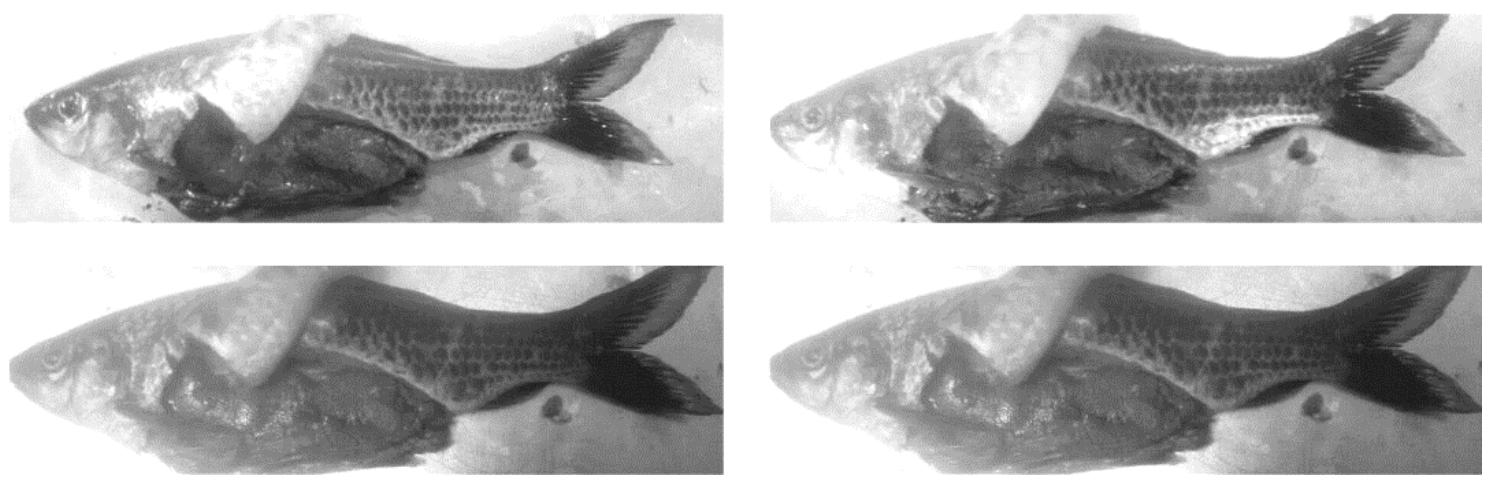

Figure 4. Egg profile of Ostechilus vittatus from Kuningan District, West Java, Indonesia 

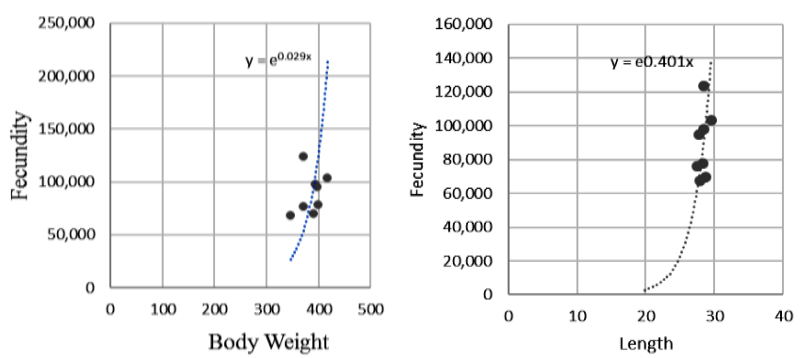

Figure 5. The relationship between body weight and fecundity (left) and the relationship between length and fecundity (right) in Cianjur District, West Java, Indonesia
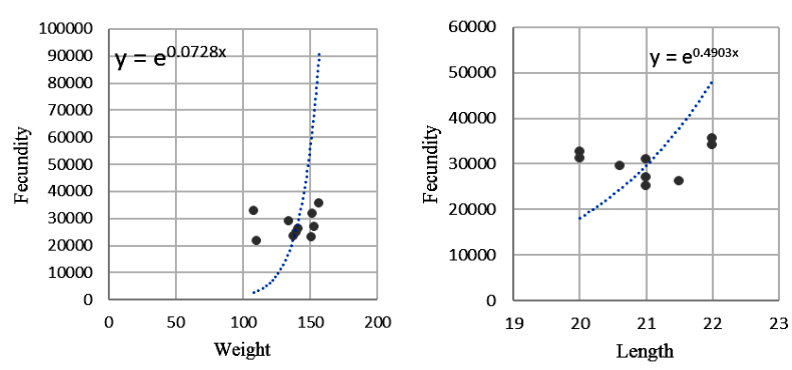

Figure 6. The relationship between body weight and fecundity (left) and the relationship between length and fecundity (right) in Tasikmalaya District, West Java, Indonesia
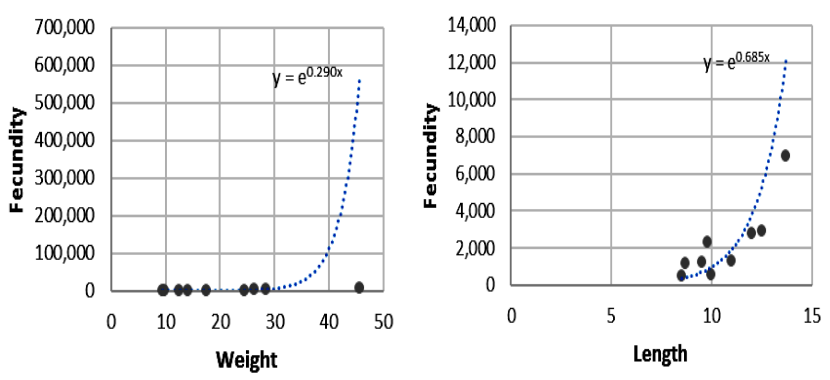

Figure 7. The relationship between body weight and fecundity (left) and the relationship between length and fecundity (right) in Kuningan District, West Java, Indonesia

Table 2. Average gonad maturity level of Osteochilus vittatus in Cianjur, Tasikmalaya and Kuningan districts, West Java, Indonesia

\begin{tabular}{lc}
\hline Districts & Gonad Maturity Level (GML) \\
\hline Cianjur & VI $(100 \%)$ \\
Tasikmalaya & IV $(50 \%)$ \\
Kuningan & V $(55,56 \%)$ \\
\hline
\end{tabular}

Table 3. Osteochilus hasseltii length and weight relationship in Cianjur, Tasikmalaya and Kuningan districts, West Java, Indonesia

\begin{tabular}{lllll}
\hline District & WL relationship & a value & b value & $\mathbf{R}^{\mathbf{2}}$ \\
\hline Cianjur & $\mathrm{W}=0.03 \mathrm{~L}^{2.95}$ & 0.03 & 2.95 & 0.94 \\
Tasikmalaya & $\mathrm{W}=0.04 \mathrm{~L}^{2.89}$ & 0.04 & 2.89 & 0.93 \\
Kuningan & $\mathrm{W}=0.04 \mathrm{~L}^{2.79}$ & 0.04 & 2.79 & 0.95 \\
\hline
\end{tabular}

Distribution of Gonad Maturity Level (GML) in Cianjur is in the range of 22-25 cm length at the level of GML VI of $100 \%$. The length of the fish in Tasikmalaya had a range from 16 to $18 \mathrm{~cm}$ at GML level IV, V and VI, but dominated on GML IV at $50 \%$. The length of the fish in Kuningan ranged from 6.5 to $7.4 \mathrm{~cm}$ both at the level GML IV, with the size 8.3 to 10.2 at GML V and $11-13$ at GML VI but dominated at GML V that is equal to $50 \%$ (Table 2). This is in line with research by Rochmatin et al. (2015) which examines the aspects of the growth and reproduction of fish in Rawa Pening, Semarang showing the average GML V.

\section{Length-weight correlation}

Weight can be considered as a function of length. By analyzing the length-weight correlation of the fish, the growth pattern can be identified. Furthermore, it can be seen whether the fish's body is fat or thin (Effendie 1997). Effendie (1979) quotes if the length and weight are plotted in a picture, it will get an equation $\mathrm{W}=\mathrm{aLb}$. $\mathrm{b}$ is $\mathrm{a}$ constant, the square value showing the growth pattern. Length-weight correlation can be used to look at the fish water condition factor. The greater the $b$ value, the better the condition of the water environment.

Length-weight correlation can be identified from the constant $b$ value, i.e., if $b=3$, the formed correlation is isometric (the length is balanced with weight gain). If $b \neq$ 3 , the correlation is allometric and if $b>3$, the correlation is positive allometric meaning that weight gain is faster than the length, showing the plump body type. If $b<3$, the correlation is allometric negative that the length is faster than weight gain, showing the bony body type (Effendie 2002).

From the analysis of the length-weight correlation, it could be identified that the equation of the correlation in Cianjur is $\mathrm{W}=\mathrm{W}=0.03 \mathrm{~L}^{2,95}$; Tasikmalaya is $\mathrm{W}=0.04 \mathrm{~L}^{2.89}$ and Kuningan is $\mathrm{W}=0.04 \mathrm{~L}^{2.79}$. From the $\mathrm{b}$ value, the fish from the sampling area have a negative allometric growth pattern (Table 3). This is consistent with the growth pattern of blue mackerel (Scomber australasicus) in the Natuna Sea, which means that the length is faster than weight gain (Nugroho et al. 2013). Similarly, according to Nehemia et al. (2012) who conducted research on tilapia farmed in freshwater, with $\mathrm{b}$ value $=2.94$. In addition, flathead gray mullet (Mugil cephalus) and freckled hawkfish (Ambassis kopsii) also have a negative allometric growth pattern (Mulfizar et al. 2012).

According to Bagenal and Braum (1968), factors that cause the $b$ value differences are environmental conditions, fish stock differences within the same species, stage of development, sex, gonad maturity, even the time differences due to changes in the entail.

The $\mathrm{R}^{2}$ values of length-weight correlation in various districts show the value from 0.93 to 0.95 , which means the data is very closely related. This is in line with research report by Koffi et al. (2014) that the $\mathrm{R}^{2}$ was scored between 0.46 to 0.94 and by Satrawaha and Pilasamorn (2009) with $\mathrm{R}^{2}$ approaching 0.95 .

In conclusion, the relationship between body weight and fecundity of Osteochillus vittatus from Cianjur, 
Tasikmalaya and Kuningan District are $y=e^{0,024 x}, y=$ $\mathrm{e}^{0,0728 \mathrm{x}}, \mathrm{y}=\mathrm{e}^{0,2902 \mathrm{x}} \mathrm{b}<3$ so the growth was allometric negative. The relationship between body length and fecundity of Osteochillus vittatus from Cianjur, Tasikmalaya, and Kuningan district are $\mathrm{y}=\mathrm{e}^{0,413 \mathrm{x}}$, $\mathrm{y}=\mathrm{e}^{0,4903 \mathrm{x}} \mathrm{y}=\mathrm{e}^{0,6859 \mathrm{x}}$. The GML of Osteochillus vittatus in Cianjur is GML IV (50\%), Tasikmalaya is GML VI (100\%), and Kuningan is GML V (55,56\%). The relationship between length and body weight of Osteochillus vittatus from Cianjur, Tasikmalaya and Kuningan District are $\mathrm{W}=0,03 \mathrm{~L}^{2,95}, \mathrm{~W}=0.04 \mathrm{~L}^{2.89}$ and $\mathrm{W}=$ $0.04 \mathrm{~L}^{2.79}$. The $O$. vittatus from Kuningan proved to be of the size that was best used as a sample fish with eggs of optimum volume.

\section{ACKNOWLEDGEMENTS}

We would like to express my sincere gratitude to the research assistant, Lantun Paradhita Dewanti and Akhmad Hafiz Kurniawan of Faculty of Fisheries and Marine Science, Universitas Padjadjaran Jatinangor, Sumedang, Indonesia. We also would like to acknowledge the generosity of Rector of Universitas Padjadjaran, Sumedang, Indonesia for the Academic Leadership Grant.

\section{REFERENCES}

Bagenal TB, Braum E. 1968. Eggs and early life history. In: Ricker W.E. (ed.) Methods for Assessments of Fish production in Fresh Water. Blackwell Scientific Publication, Oxford.

Brodziak J. 2012. Fitting length-weight relationships with linear regression using the log-transformed allometric model with bias correction. Pacific Islands Fish. Sci. Cent., Natl. Mar. Fish. Serv., NOAA, Honolulu, HI 96822-2396. Pacific Islands Fish. Sci. Cent. Admin. Rep. H-12-03, 4.

Effendie MI. 2002. Fisheries Biology. Yayasan Pustaka Nusantara. Yogyakarta. [Indonesian]

Effendie MI. 1979. Method in Fisheries Biology. Yayasan Dewi Sri, Bogor. [Indonesian]
Isa MM, Rawi CSM, Rosla R, Shah SAM. 2010. Length-weight relationships of freshwater fish species in Kerian River Basin and Pedu Lake. Res J Fish Hydrobiol 5: 1-8

Koffi BK, Berté S, Koné T. 2014. Length-weight Relationships of 30 Fish Species in Aby Lagoon, Southeastern Côte d' Ivoire. Curr Res J Biol Sci 6: 173-178.

Mansor, Azizah M, Hamid SM. 2015. Length-weight relationship and condition factor of fish populations in Temengor Reservoir: Indication of environmental health. Sains Malaysia 44 (1): 61-66

Muchlisin ZA, Batubara AS, Siti-Azizah MN, Adlim M, Hendri A, Fadli N, Muhammadar AA, Sugianto S. 20015. Feeding habit and length weight relationship of keureling fish, Tor tambra Valenciennes, 1842 (Cyprinidae) from the western region of Aceh Province, Indonesia. Biodiversitas 16: 89-94.

Mulfizar, Muchlisin ZA, Dewiyanti. 2012. Hubungan panjang berat dan faktor kondisi tiga jenis ikan yang tertangkap di perairan Kuala Gigieng, Aceh Besar, Provinsi Aceh. Depik 1 (1): 1-9.

Murtejo HE. 2008. Feed Egg Stimulant Effectiveness in the Maturation of Gonads and Productivity of Red Fin Shark (Epalzeorhynchos frenatum). [Hon. Thesis]. Institut Pertanian Bogor, Bogor. [Indonesian]

Nehemia A, Maganira JD, Rumisha D. 2012. Length-weight relationship and condition factor of Tilapia species grown in marine and freshwater ponds. Agric Biol J North Amer 3 (3):117-124

Nugroho ES, Efrizal T, Zulfikar A. 2013. Condition factor and heavy length relationship selikur's fish (Scomber australasicus) at Natuna's Oceanic one that is landed at Pelantar Kud, Tanjungpinang City. Jurnal Universitas Maritime Raja Ali, Kepulauan Riau. http://jurnal.umrah.ac.id/wp-content/uploads/2013/08/EndiawanSetyo-N-090254242022.pdf

Rochmatin SY, Solichin A, Saputra SW. 2014. The growth aspects and reproduction of nilem (Osteochilus hasseltii) in Rawa Pening, Sub District of Tuntang, Semarang Regency. Diponegoro J Maquares 3 (3):153-159.

Satrawaha R, Pilasamorn C. 2009. Length-weight and length-length relationships of fish species from the Chi River, Northeastern Thailand. J Appl Ichtyol 25 (6): 787-788

Subagja J, Gustiano R, Winarlin L. 2006. Fish preservation of nilem (Osteochilus hasseltii C.V) through breeding technology. Balai Riset Perikanan Budidaya Air Tawar, Bogor. [Indonesian]

Syandri H, Azrita, Junaidi. 2015. Fecundity of bonylip barb (Osteochilus vittatus; Cyprinidae) in different waters habitats. Intl J Aquat Stud 2 (4): 157-163.

Yudhistira TE. 2013. Effect of Testis Cows Flour on Gonads Maturity Level and Fecundity of Nilem (Osteochilus hasseltii). [Thesis]. Faculty of Fisheries and Marine Sciences, Universitas Padjajaran, Sumadeng. [Indonesian] 